\title{
RACING CIRCUITS AND THEIR GEOMETRIC DESIGN CHARACTERISTICS
}

Professional paper/Stručni rad

Hrvoje Kmoniček

(Received: 03 July 2019; accepted:01 November 2019)

SB Consulting j.d.o.o., mag.ing.aedif.

Filip Ruška

Zavod za urbanizam i izgradnju d.d. Osijek, mag.ing.aedif.

Ivana Barišić

University of Osijek, Faculty of Civil Engineering and Architecture Osijek, Associate Professor

Corresponding author: ivana@gfos.hr

\begin{abstract}
Existing race circuits were created using one of the two methods - intuition or engineering. Under the intuitive approach, the track was completely built by adapting to the terrain and environment in which it is located. The engineering approach to racing circuit development involves planning, designing, and building a car park at a specific location to accommodate all the users. Racing circuit design is based on recommendations depending on the type of race to be held. In Croatia, Croatian Car and Karting Federation issued the Circular Motor Racing Track Ordinance that defines the minimum requirements for organization and equipment of racing circuits. This paper presents a conceptual design of a racing circuit that is designed as per international requirements (FIA and FIM regulations) to host international sports events. This conceptual circuit is planned to be located in Osijek, which is the largest city in Eastern Croatia. It has a great location potential for becoming a motor sport center. The selected location has a possibility of venue extension for additional content, such as a test vehicle polygon, training center, and karting racing circuit. The conceptual design includes all the criteria, such as horizontal and vertical alignments, water drainage, pavement design, safety measures, and construction elements.
\end{abstract}

Keywords: racing circuits; design; FIM; FIA; conceptual design; technical regulations

\section{PROJEKTNE KARAKTERISTIKE AUTOMOTO STAZA}

Sažetak: Postojeće su automoto staze izgrađene na jedan od dva načina - intuitivno ili inženjerskim pristupom. Pod intuitivnim načinom podrazumijeva se da je staza u potpunosti izgrađena tako da se prilagodila terenu i okruženju u kojemu se nalazi. Inženjerski način razvoja trkaće automoto staze uključuje planiranje, projektiranje i izgradnju staze na određenoj lokaciji tako da odgovara onima koji će je koristit. Projektiranje trkaće staze temelji se na preporukama, ovisno o vrsti utrke koja će se na njoj održavati. Hrvatski auto i karting savez izdao je Pravilnik o stazama za kružne autoutrke koji definira minimalne zahtjeve za pripremu i opremanje staza za autoutke, no unutar ovoga rada idejno je rješenje automoto staze izrađeno prema međunarodnim zahtjevima (FIA i FIM propisi) kako bi se prilagodilo međunarodnim sportskim događanjima. Ova idejna automoto staza planirana je u Osijeku, koji kao najveći grad u istočnoj Hrvatskoj ima izvrstan potencijal za izgradnju sportskog centra za automoto utrke. Odabrana lokacija staze omogućava njezino proširenje u slučaju potrebe za dodatnim sadržajem, kao što su poligoni testnih vozila, centar za trening vožnje ili staza za karting utrke. Idejno rješenje obuhvatilo je sve dijelove koji su potrebni za izvedbu staze, kao što su horizontalno i vertikalno profiliranje staze, oborinska odvodnja, kolnička konstrukcija, sigurnosne mjere u obliku konstruktivnih elemenata i sl.

Ključne riječi: automoto staze; projektranje; FIM; FIA; idejno rješenje; tehnički propisi 


\section{INTRODUCTION}

The first internal combustion engine car races began shortly after the emergence of vehicles in the market. The first organized competition took place on April 28, 1887 in France on a $2 \mathrm{~km}$ long racing circuit [1]. Since then, people have been looking for ways to spice up this new form of sport. Cars had to be made faster and better, racing circuits needed to be interesting, drivers brave and capable, and above all, the safety of all those involved in the race had to be ensured. The first track that was built solely for the purpose of hosting such races was Brooklands in England. The concrete pavement racing circuit opened in 1907 and closed in 1939 [2]. The races were extremely popular and attracted large crowds. Even today, car racing is a popular form of entertainment with large number of viewers and competitors. With a sudden development in sports and the automotive industry in general, it was necessary to have an infrastructure that could meet the demand.

Existing race circuits were created using one of the two techniques - intuition or engineering. Under the intuitive approach, the track was not designed. It was completely built by adapting to the terrain and the environment in which it was located. For example, the Brands Hatch racing circuit, England (Figure 1) was spontaneously created by a group of cyclists who came across a piece of terrain perfect for a bicycle ride that evolved over time into today's form [3]. The second approach developed along with road infrastructure development. Engineering approach of racing circuit development involves planning, designing and building a car park at a specific location. Such a way of track construction has been quite popular in the past decades and has created several great avenues around the world. The advantage of this approach is that racing circuits are designed and constructed to accommodate all those who will use them. Firstly, the track must be safe. It must include various supporting facilities, buildings, and the entire infrastructure that comes along with it. Geometric requirements must be met to ensure good visibility, stability of construction, and high quality drainage. For such an investment to be cost-effective and sustainable, it is necessary to conduct cost-benefit studies, various analysis, estimates, and optimization. With a good engineering approach, many problems are resolved in a short time and subsequent modifications are rarely needed.

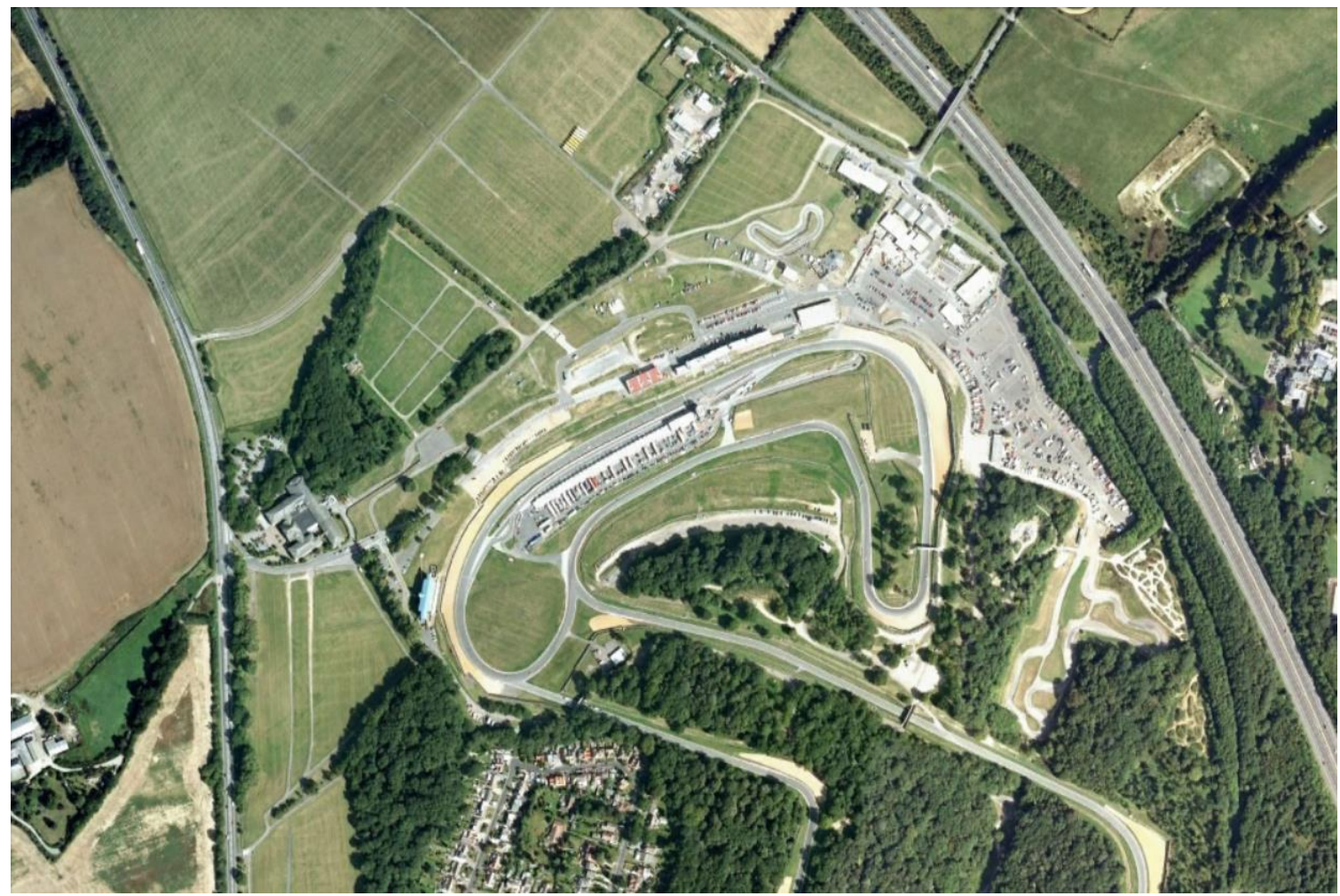

Figure 1 Brands Hatch racing circuit, England 


\section{RACING CIRCUIT GEOMETRIC DESIGN SPECIFICS}

There are no strict rules for designing racing circuits as there are in public road design. Racing circuit design is based on recommendations of international organizations depending on the type of racing to be held on it. FIA (Fédération Internationale de l'Automobile) is the main federation for motor racing and FIM (Fédération Internationale de Motocyclisme) is the main federation for organizing motorcycle racing. Similarly, CIK (Commission Internationale de Karting) is the main organization for karting races. FIA issues technical regulations [4] that its members must adhere to for maintaining the right to organize sporting events. All new projects or major maintenance and reconstruction projects must be approved by FIA.

Technical regulations are divided based on race types, i.e., circular racing, rally racing, off-road races, hill climbs, historic races, rules for recording speed records, and regulations for homologation and safety. Design criteria for racing circuits are contained in the regulations for homologation.

Although the FIA and FIM are two similar organizations, FIM's regulations [5] for design of racetracks are significantly more detailed and extensive. Table 1 compares the technical recommendations of FIA and FIM $[4,5]$

\begin{tabular}{c|cc}
\hline & FIA regulation & FIM regulation \\
\hline License grade & $1,2,3,4,6$ & $\mathrm{~A}, \mathrm{~B}, \mathrm{C}, \mathrm{D}, \mathrm{E}$ \\
Maximum straight section length & $2 \mathrm{~km}$ & $1 \mathrm{~km}$ \\
Circuit length & $7 \mathrm{~km}$ & $4.2-4.5 \mathrm{~km}$ \\
Track width & $12 \mathrm{~m}$ & $12 \mathrm{~m}$ \\
Starting grid width & $15 \mathrm{~m}$ & $14 \mathrm{~m}$ \\
Track width change gradient & $1: 20$ & $1: 20$ \\
Transversal inclination along straights & $1.5 \%-3 \%$ & $1.5 \%-3 \%$ \\
Transversal inclination in corners & $10 \%$ & $5 \%$ \\
Track verges width & $1 \mathrm{~m}-5 \mathrm{~m}$ & $2 \mathrm{~m}$ \\
Run-off area slope & $3 \%$ downwards; $25 \%$ upwards & $3 \%$ downwards; $10 \%$ upwards \\
Distance to first corner & $250 \mathrm{~m}$ & $250 \mathrm{~m}$ \\
\hline
\end{tabular}

\section{Table 1 Comparison of FIA and FIM racing circuit regulations $[4,5]$}

FIM technical regulations define three main terms for racing circuit design: the course, circuit, and track. The term course represents a road or track, and the inherent installations used for automobile competitions. Circuit is a closed course including inherent installations, beginning and ending at the same point, built or adapted specifically for automobile racing. Course and circuit may be permanent, semi-permanent, or temporary structures. The track is a road specially built or adapted for circuit competitions and defined by the outer edges of the racing surface [4]. FIM defines the track surroundings as an area between the outer edges of the track and the first line of protection while service areas are defined as areas between the first and second line of protection [5]. Surface water drainage from tracks, parks and other operational surfaces are major design priorities.

Table 1 shows that most of the limit values set by regulations is derived from driving dynamics and geometrical characteristics of vehicles to which the regulation applies. Racing cars occupy more space than motorcycles, hence, they need a wider startfinish straight. Higher car stability allows higher transversal inclines in corners. Generally, the highest level of competition for cars and motorcycles should not be allowed on the same track. However, in practice FIA and FIM often set a compromise and use the same racing circuits for their competions. The track in Monaco is an example that does not match various parameters set in earlier mentioned regulations (minimum width, dimension of run-off areas, ramps, etc.). However, Monaco is not a permanent track construction, and FIA neglects these shortcomings, as it is highly profitable.

In Croatia, Croatian Car and Karting Federation issued a Circular Motor Racing Track Ordinance [6] that defines minimum requirements for preparing and equipping racing circuits. It defines a minimum racing circuit length of $2000 \mathrm{~m}$, minimum track width of $6 \mathrm{~m}$, track width at start line of at least $9 \mathrm{~m}$, and starting line distance to the first corner must be at least $200 \mathrm{~m}$. All corners should have a well-maintained and secured safety zone. If this cannot be constructed, the corner must be protected by concrete blocks or bumpers along with a tire-protecting wall. Dangerous corners must be marked by distance boards $(300,200,100$, and 50). The pavement must be asphalt. 
For aerodromes used as racing circuit, the pavement can be concrete that must be thoroughly cleaned and degreased. Ordinance defines paddock as a space for parking and maintenance of racing cars. It should be asphalt paved, clean and should have a sanitary area, drinking water, and electricity. Catering facility must be at a maximum distance of $500 \mathrm{~m}$.

According to Croatian laws and regulations [7, 8], environmental impact assessment must be carried out for all sports and recreational centers over 10 ha. Croatian ordinance defers FIA and FIM requirements. Hence, Croatian car and karting federation can issue only national licenses, whereas FIA and FIM issue international licenses for racing circuits. This paper presents a conceptual design of a racing circuit that is designed as per international requirements (FIA and FIM regulations) to accommodate international sports events.

In road design, selecting appropriate horizontal curve elements is a critical stage in terms of traffic safety and driving comfort. The same applies to racing circuit design. Minimum curve radius is affected by many factors. Some new studies are determining a minimum horizontal curve radius based on lateral Jerk (lateral acceleration changing per unit time occurring in horizontal curves) [9].

Besides selecting appropriate horizontal curve radii, vehicle trajectory or racing line is an important design parameter. When designing public roads, vehicles are expected to stick in one row per traffic lane. At a horizontal curve, vehicle trajectory follows traffic lane geometry and has the same radius as the radius of the horizontal curve depending on whether the vehicle is traveling on the inner or outer curve lane. For racing circuits, there are no traffic lanes and drivers can use the entire track width, and in special cases, the curbs. The goal is quickest passage on the track circuit. Hence, racers will intuitively shorten the straights and extend the curves on the track. One such passage through the horizontal curve is shown in Figure 2.

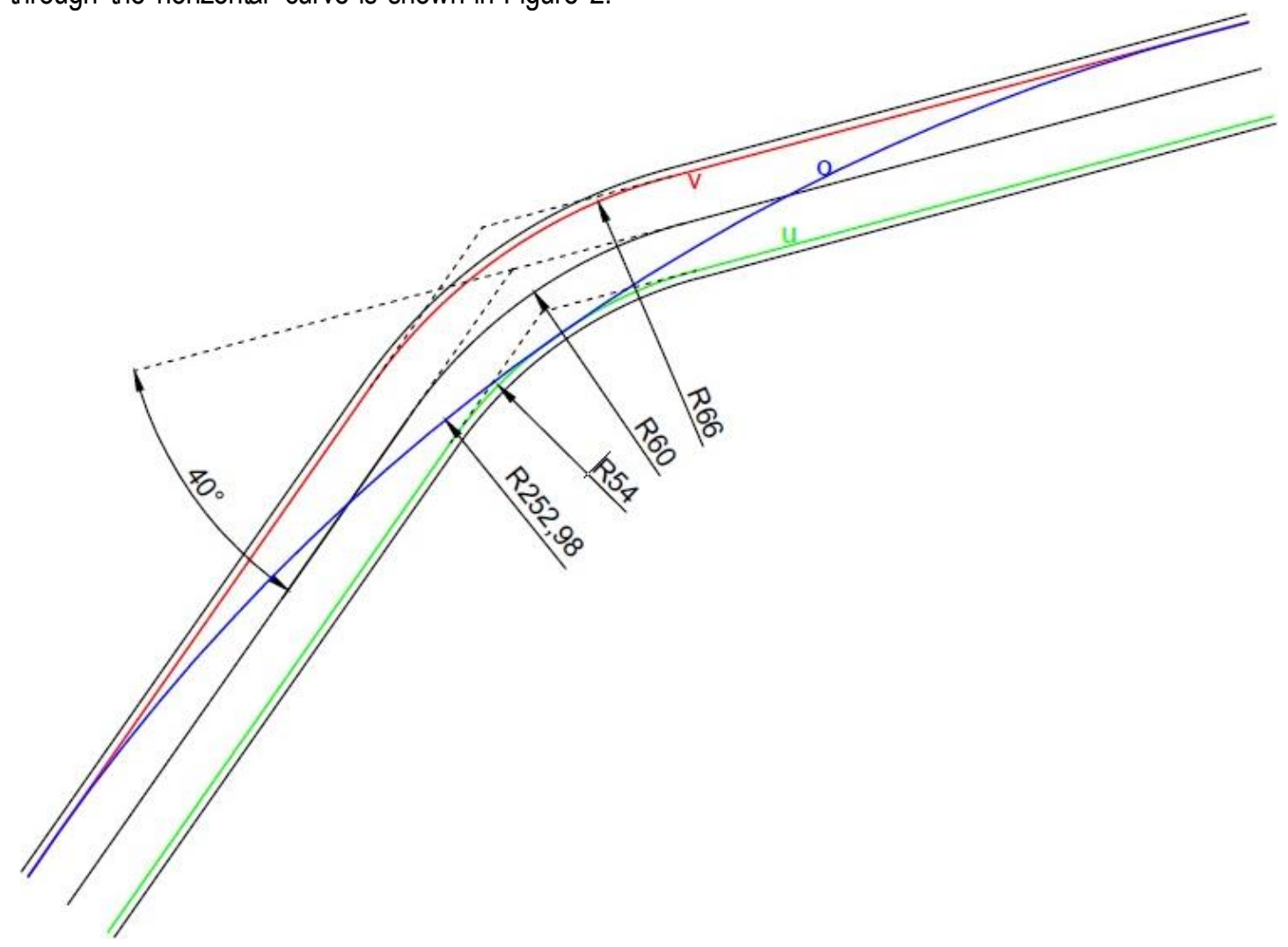

Figure 2 Possible driving routes through the individual horizontal curve [10]

Figure 2 shows a racing track having a total width of $14 \mathrm{~m}$ and has a radius of $60 \mathrm{~m}$. The track changes direction by $40^{\circ}$. A driver's goal is to pass the curve as fast as possible to minimize the time of passage. If the driver decides to follow the line "U" marked in green in Figure 2, he will secure the shortest path possible. Considering the smallest radius of turning of only $54 \mathrm{~m}$, the speed at which he travels must be decreased. Line "V' is the outer line that represents a longer path through the curve but also gives a greater radius of rotation and allows faster speed than 
"U" line. The "O" line, marked with blue, represents the optimal route. It enables the highest radius of rotation and allows a high speed of passage. For minimum curve radius calculation on public roads, equation 1 is used [11].

$R_{\text {min }}=\frac{V_{p}^{2}}{127\left(f_{R d o p}+q_{\max }\right)}$

Where,

$\mathrm{R}_{\min }-\mathrm{min}$. horizontal curve radii [m]

$V_{p}$ - travel speed $[\mathrm{km} / \mathrm{h}]$

$f_{\text {Rdop }}$ - friction coefficient

$q_{\max }$ - max transverse gradient [\%]

For three different lines shown in Figure 2, assume 0\% transverse gradient and a friction coefficient of 1.1 [12], the following trajectory velocities were obtained:

$$
\begin{aligned}
& v_{U}=86 \mathrm{~km} / \mathrm{h} \\
& v_{V}=96 \mathrm{~km} / \mathrm{h} \\
& v_{O}=188 \mathrm{~km} / \mathrm{h}
\end{aligned}
$$

Line "O" is the fastest line passing through the corner and it is termed as vehicle trajectory or racing line. It varies from corner to corner, characterized by the braking point, turn-in point, apex, and exit point. For single corners, ideal driving line is easy to determine. However, for an S-turn or other combination of consecutive corners, the ideal driving line changes and its calculation becomes complicated. In such combinations, the driver aims to achieve the earliest corner exit by achieving the shortest time and fastest possible speed. In mathematical terms, the driving line becomes an optimization problem in which the shortest time is required along the boundary conditions. Some parameters influencing the optimization problem are:

- The frictional force that the tire can withstand on the influence of side and longitudinal forces

- The minimum vehicle rotation radius

- Maximum vehicle speed

- Maximum vehicle acceleration and braking characteristics

For detailed analysis, if the track is viewed three-dimensionally, the calculation must include transverse gradients and vertical alignment characteristics. Hence, for appropriate racing circuit design, the assessment of driving behavior and safety using multi-stage methodology and driving simulator should be integrated in the overall designing process [13].

The racing line depends on the track and its geometric characteristics, quality of asphalt, quality of tires, vehicles' characteristics, as well as the driver's skill. Hence, racing line cannot be determined precisely and the track dimension cannot rely completely on its appearance. Usually, general driving line is designed first and corner modification is done accordingly. By designing the racing line, dimensions, position, and shape of run-off areas can be derived. This approach was used in this paper.

\section{RACING CIRCUIT CONCEPTUAL DESIGN FOR THE CITY OF OSIJEK}

\subsection{Potential}

There are over 200 FIA homologated racetracks in the world that are used for different types of competitions like F1, F2, F3, GT, etc. Among the 200 tracks, some are more famous than others, some are in use since decades, and some are in use for a very short period. Tracks like Barcelona, Monza, and Interlagos have a rich and turbulent history, whereas tracks like Yas Marina, Sochi, and Korea are still new, and it remains to be seen how they will stand the test of time. Nevertheless, no matter how old or young the track is, it has to adhere to regulations if it has to stay in use. Table 2 shows how different tracks satisfy current strict regulations and the differences between them. 
Racing circuits and their geometric design characteristics

\begin{tabular}{|c|c|c|c|c|c|c|c|c|c|c|}
\hline Circuit & Yas Marina & Bahrain BIC & Barcelona & Monza & Interlagos & Korea & Monaco & Sochi & Spa & Suzuka \\
\hline Lap length [km] & 5.554 & 5.411 & 4.655 & 5.793 & 4.309 & 5.615 & 3.337 & 5.848 & 7.004 & 5.807 \\
\hline Race laps & 55 & 57 & 66 & 53 & 71 & 55 & 78 & 53 & 44 & 53 \\
\hline $\begin{array}{l}\text { Race distance } \\
{[\mathrm{km}]}\end{array}$ & 305.355 & 308.238 & 307.104 & 306.72 & 305.909 & 308.96 & 290.286 & 309.745 & 308.052 & 307.471 \\
\hline Turns & 21 & 15 & 16 & 11 & 15 & 18 & 19 & 18 & 19 & 18 \\
\hline $\begin{array}{l}\text { Maximum speed } \\
{[\mathrm{km} / \mathrm{h}]}\end{array}$ & 339 & 321 & 317 & 337 & 323 & 313 & 290 & 343 & 320 & 328 \\
\hline $\begin{array}{c}\text { Distance to turn } \\
\text { one }[\mathrm{m}]\end{array}$ & 305 & 265 & 730 & 638 & 334 & 250 & 111 & 1029.5 & 271 & 405 \\
\hline Full throttle [\%] & 59 & 66 & 56 & 76 & 50 & 62 & 43 & 50 & 70 & 66 \\
\hline $\begin{array}{l}\text { Longest flat-out } \\
\text { section [m] }\end{array}$ & 1223 & 1205 & 1310 & 1520 & 1394 & 1125 & 669 & 1073 & 2015 & 994 \\
\hline
\end{tabular}

Table 2 Characteristics of existing racing circuits [10]

In Europe, 19 countries have at least one track with an international FIA license [14]. The only racing circuit in the region that is in Croatia is Automotodrom Grobnik. Although Grobnik currently does not have any international license, racing events are organized regularly on an average of 246 days a year. Apart from Grobnik, there are a few places like Bura in Primorsko-Goranska Kotar County and ORYX Safe Drive Center in Mičevac near Velika Gorica, where car and motorcycle races are held occasionally. In Osijek, street races are organized at Osijek-Čepin aerodrome. This location is not suited as a racing circuit as it collides with traditional and rich sports aviation situated in Osijek-Čepin aerodrome since 1962.

Figure 3 compares the number of inhabitants for international FIA licensed racing circuits [14] of some European countries according to the data on population [15]. It can be seen that the population of Croatia $(4,255,374$ inhabitants) is well suited to the ratio of population and the number of racing circuit for other countries. Hence, Croatia can optimally accompany one internationally licensed racing circuit.



Figure 3 Number of inhabitants per existing racing circuit

As stated earlier, Grobnik has the potential to become an FIA approved racing circuit. However, defiance is its location. It is very close to Italy, which boasts 13 internationally renowned racing circuits, of which 3 have a GRADE 1 license and the ability to organize Formula 1. On the other hand, East Croatia borders BosniaHerzegovina, Serbia, and indirecty Montenegro, Kosovo, Bulgaria, and Romania, countries that do not have any licensed racing circuits. The nearest licensed track is located in Hungary. Hence, Osijek as the largest city in Eastern Croatia has a great location potential for becoming a motor sport center.

\subsection{Racing circuit conceptual design}

The conceptual design of a racing circuit is created using national and international (FIA and FIM) regulations and recommendations [4-6]. Firstly, it is necessary to choose a potential location for the future venue. Location selection 
is based on the vicinity of an existing city road network and distance from residential buildings (Figure 4). This is to reduce noise and exhaust emission influence on the nearby population. The selected location should have the possibility of venue extension in case of necessity for additional content such as a test vehicle polygon, training center or karting racing circuit.

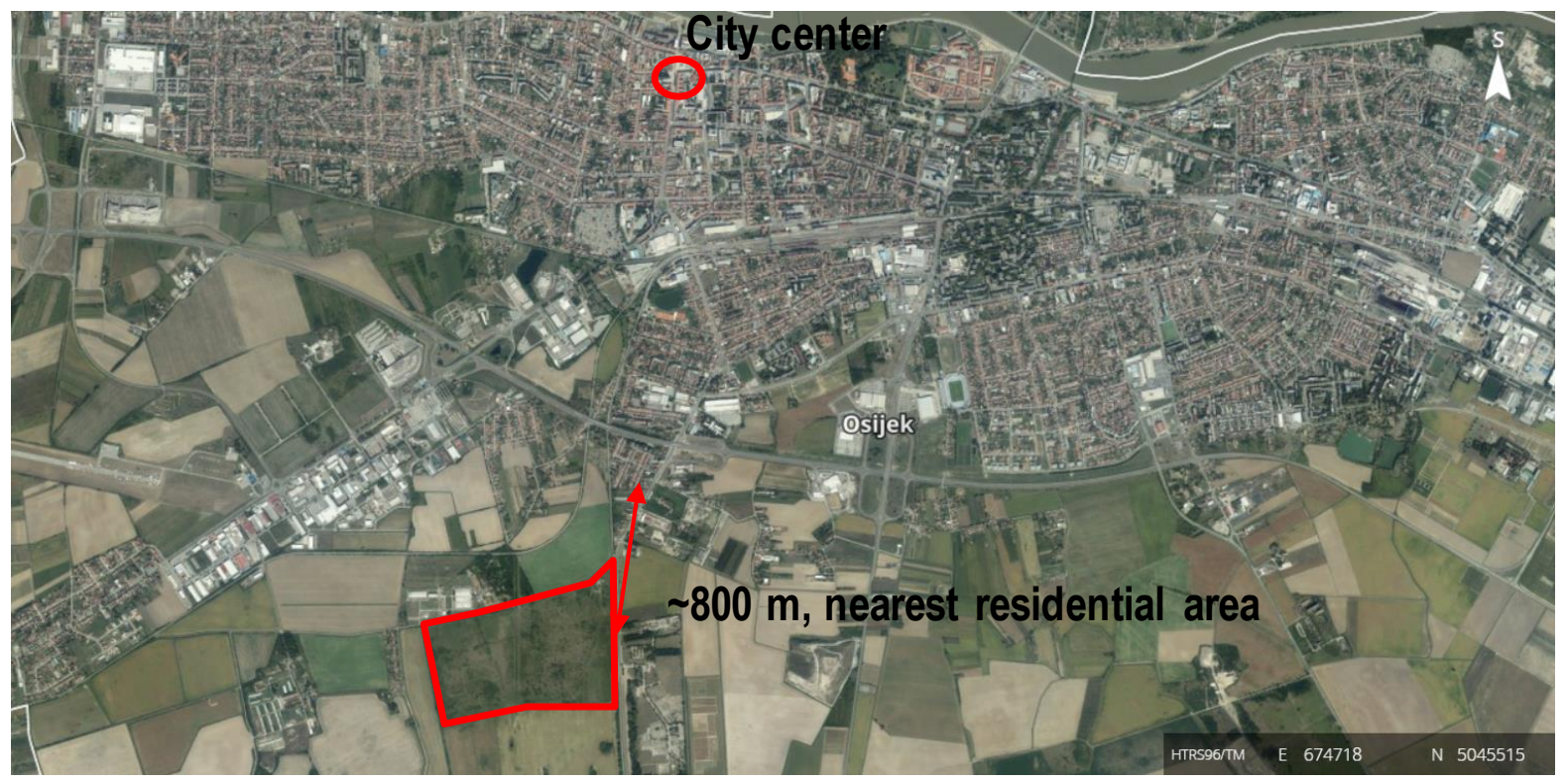

Figure 4 An overview of a wider area with marked subject location

As the layout of the track is not subjected to any rules, each designer is free to work alone or in co-operation with drivers, race organizers, or investors to design the best solution that will adapt to the existing terrain and surroundings. The final track solution should present a challenge for drivers and enable good competition. The standard practice in modern racing circuit design is to provide at least one long straight that will serve as a start/finish with pit-lane, garages, and paddock. Additionally, some tracks have one or two long straight sections along with the startfinish straight. At the end of long straight sections, it is necessary to provide sufficiently wide run-off areas and a service road behind them. With this conceptual design, terrain constrains prevents design of long straight sections. Hence, several medium long straights connected by fast curves are designed. This way, the race will be interesting and the circuit will not affect good competition negatively.

Corner design is not subjected to any rules. The only rule is that the first corner must have a radius less than $300 \mathrm{~m}$ and with a direction change greater than $45^{\circ}$.

Transition curves are not used within this conceptual design as current regulations (national and international) does not define it in detail. Racing cars create high aerodynamic thrust resulting in high mechanical grip forces. With specially designed tires, it can withstand higher lateral forces and are stable when cornering. Therefore, the need to design transition curves is reduced.

Racing circuits are designed to maximize available space and accommodate several circuit configurations. The goal is to design an interesting and safe racing circuit for drivers and spectators alike. This is achieved by a combination of fast long turns and slow short turns with predetermined run-off areas. Layout of the designed racing circuit is presented in Figure 5. 


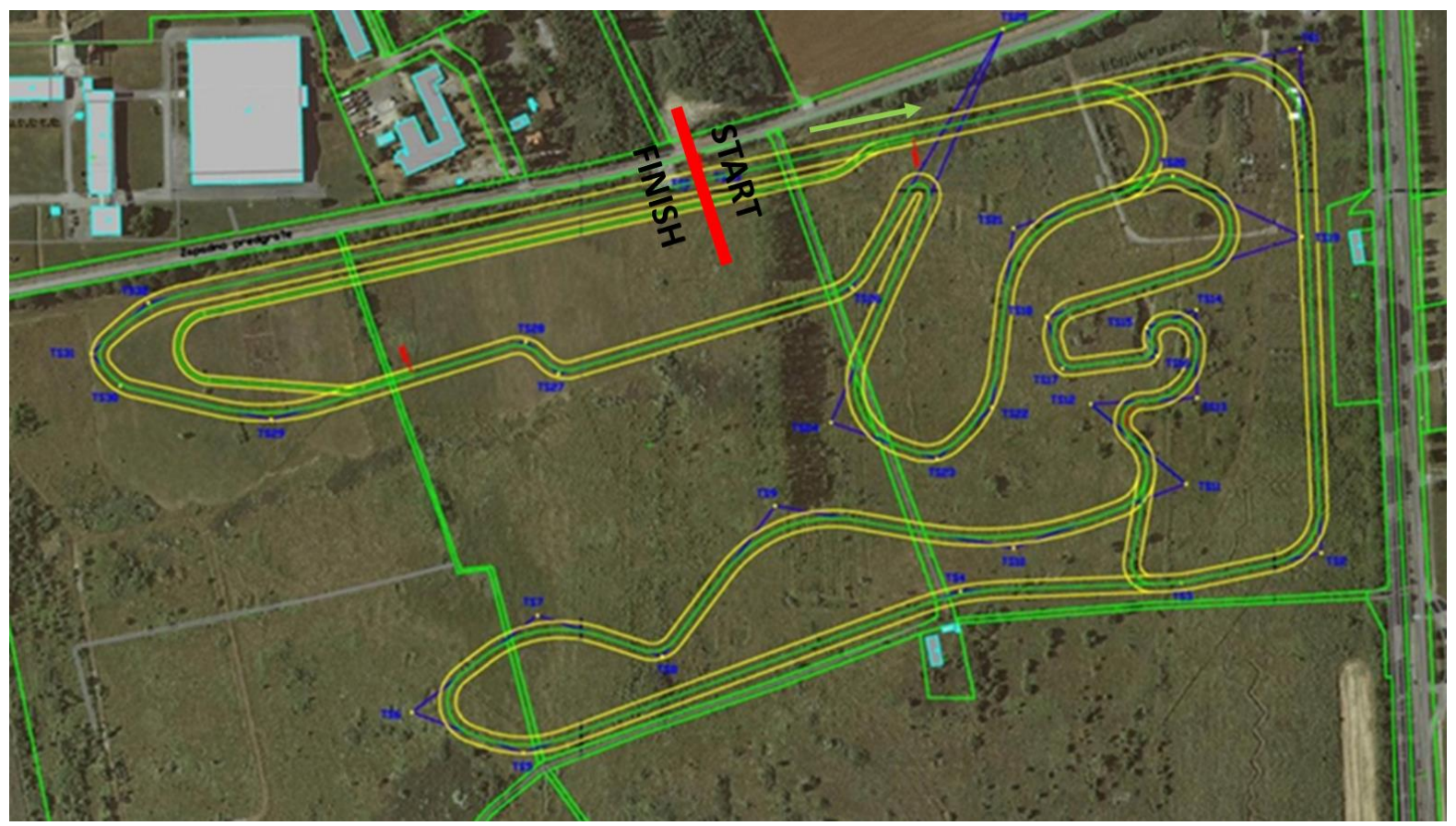

Figure 5 Racing circuit layout [10]

The starting line is $784.8 \mathrm{~m}$ long and $15 \mathrm{~m}$ wide with the first corners having $50 \mathrm{~m}$ radii as set by regulations. This layout has three circuit configurations having lengths of $2072.03 \mathrm{~m}, 3206.79 \mathrm{~m}$, and $4272.99 \mathrm{~m}$.

Vertical alignment was designed considering terrain characteristics and position of existing nearby public road. Parallel to the designed starting straight is a public road. Hence, vertical alignment should follow that of the existing road or run lower to prevent road crashes in case drivers lose control. Vertical alignment is designed by combining sections with grades of $0 \%$ to $2.4 \%$. This combination is used for making races more attractive for drivers and spectators. It compels drivers to demonstrate their driving abilities and take advantage of vehicle characteristics. Minimal vertical alignment grade of $0 \%$ is designed for racing vehicles to be left on their own strength, amount of friction and aerodynamic downforce without gravity influence. Sections with small ascent allow vehicles to use gravity for intensive braking before slow corners. This enables easier stopping within run-off areas. Sections with small decline allow faster corner exit and sections with high decline forces drivers on additional braking while turning to avoid losing the racing line and remain in the competition. More details on geometric design characteristics are presented in [10].

The circuit track width is $12-15 \mathrm{~m}$. The cross-section grade of $1.5 \%$ on straight sections and $5 \%$ in corners is designed to accommodate both FIA and FIM standards so that it is suitable for car and motorcycle races. Along the entire racing circuit, verges are designed with cross-section grade equal to that of the pavement. On the inner side of the turns, $1 \mathrm{~m}$ wide prefabricated concrete curbs are designed in red and white color (Figure 6). Outer sides of the turns are secured by $3 \mathrm{~m}$ wide shoulders and two secure zones. The first zone is asphalt paved and the second zone is unpaved gravel surface. In order to increase security measures, TECPRO energy-dispensing devices are designed (Figure 6) that can be set in different ways depending on the estimated impact force. Fences preventing the debris from endangering the security of viewers and judges are also considered. 

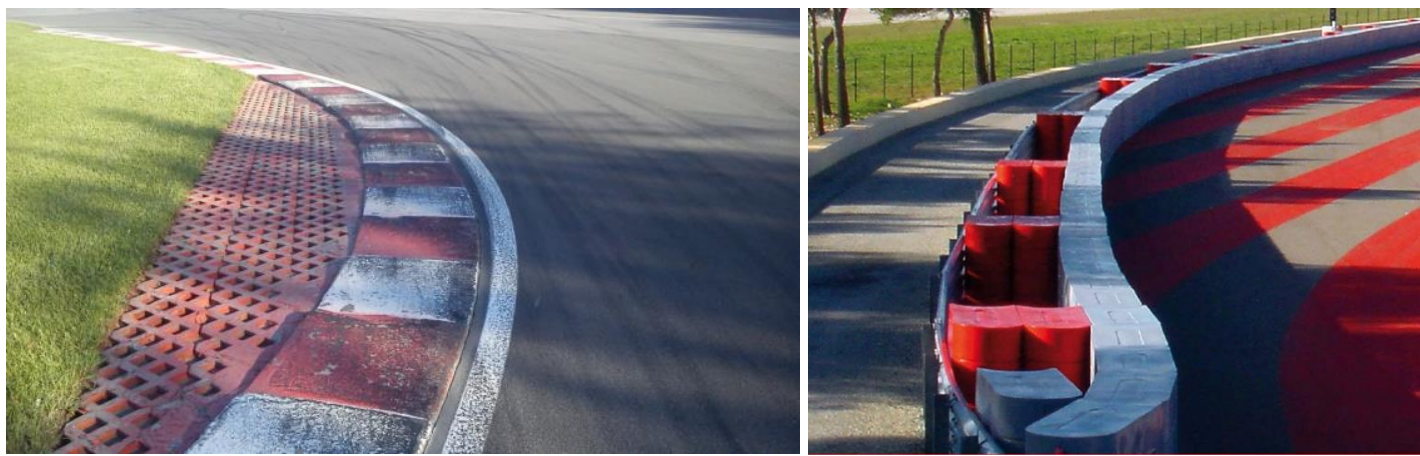

Figure 6 Inner curbs and TECPRO energy dissipation system [16, 17]

From "AASHO road test" results that provided an engineering basis for establishing maximum axle load limits [18] and experience in road design and build, it is well known that personal cars, including racing cars, have very little impact on changes in pavement bearing capacity. The pavement design for racing tracks is not related to traffic load as most of the traffic is constituted by cars and motorcycles, except in exceptional cases where heavy vehicles are used for equipment and vehicle transport, emergency services or construction equipment during construction works. Instead of the vertical axle load, extreme horizontal load due to sudden acceleration of the vehicle and intense braking must be taken into account. Additionally, for high speeds that can be achieved in corners, the structure will be loaded with high tangential forces. The requirements for pavement design in this case are:

- Good adhesion (grip)

- Surface level without working junctions

- Aesthetic appearance

- Non-sensitivity to climate impacts

- Economics

- Possibility of production and incorporation

Considering these factors and the fact that there is no established pavement design practice in such projects, the pavement structure was designed consisting of $6 \mathrm{~cm} \mathrm{AC} 16$ surf 45/80-65 AG3 M1 and minimum $40 \mathrm{~cm}$ unbound granular material (crushed rock 0/63 mm).

\section{CONCLUSION}

Investing in construction of racetracks represent a major project even for countries larger than the Republic of Croatia. The cost of such investments must be justified and should be sustainable for a wider community and not just a narrow circle of users of such facilities. When designing and constructing, detailed analysis, estimation, and optimization with cost-benefit analysis have to be done, which can only be achieved by a good engineering approach to the project. Unlike road design, access to the design of track lanes is unclear and undefined and can be reduced by adapting access to public roads. However, in an environment where human lives can be vulnerable, it must not only be good enough, that is unacceptable.

In the process of developing design approaches, test courses and driving simulations should be included to carry out multi-level analysis ensuring maximum driver safety on the track. Driver safety in such extreme conditions is at the highest level that must be met with respect to the set criteria (the fastest vehicle to use the track and its characteristics).

Recently, personal cars are increasingly becoming autonomous vehicles, and the need to control by humans will disappear in the near future. With this, the need to enjoy driving action itself will be shifted to racing tracks that are currently not sufficient to address future needs. This fact opens the possibility of developing a new market that would be focused on small (local or regional) competitions as well as open-door days on racing tracks. Additionally, along with the infrastructure that follows such a route, the possibility of inviting a variety of companies such as automobile mechanics, rent-a-car companies, retail outtets, gas stations and electric fillers, and catering establishments would open. When there are no cars and motorcycles, cyclists and runners could take the track, as it would be possible to organize concerts and similar large open-air events on the premises. Therefore, it is 
necessary to develop a good approach to design racetracks, as it is currently the case for all other public roads to meet market needs in time.

\section{ACKNOWLEDGEMENTS}

The authors acknowledge support for this study provided by Technical culture community of Osijek.

\section{References}

[1] Auto racing, https://en.wikipedia.org/wiki/Auto_racing. Accessed 30 November 302017

[2] Brooklands, https://en.wikipedia.org/wiki/Brooklands. Accessed 7 October 2017

[3] Racing circuits, http://racingcircuits.infol. Accessed 7 October 2017.

[4] FIA; Appendix $O$ to the international sporting code, 2017

[5] FIM; FIM standards for circuits, 2017

[6] Croatian car and karting federation, 2018: Circular Motor Racing Track Ordinance (in Croatian), http://www.haks. hr/pravilnici/autosportovi/18a-a01_staze.pdf, Accessed 5 September 2018

[7] Zakon o zašiti okoliša, Official gazette 80/13, 153/13, 78/15, 12/18, 118/18 (in Croatian)

[8] Uredba o procjeni utjecaja zahvata na okoliš, Official Gazette 61/14, 3/17 (in Croatian)

[9] Kilinç, A.S.; Baybura, T. 2012: Determination of minimum horizontal curve radius used in the design of transportation structures, depending on the limit value of comfort criterion lateral Jerk, FIG Working Week 2012, Knowing to manage the territory, protect the environment, evaluate the cultural heritage, Rome, Italy, 6-10 May 2012

[10] Kmoniček, H. 2018: Racing circuit conceptual design, Final thesis, Faculty of Civil Engineering Osijek (in Croatian)

[11] Pravilnik o osnovnim uvjetima kojima javne ceste izvan naselja i njihovi elementi moraju udovoljavati sa stajališta sigurnosti prometa, Official Gazette 110/01 (in Croatian)

[12] Beckman, B. 1991: The Physics of Racing, Part 2: Keeping Your tires Stuck to the Ground, Available: www.miata.net/sportPhysics/, Accessed 28 August 2019

[13] Kuhn, W. 2017: Methodology for the numerical calculation of racing lines and the virtual assessment of driving behavior for training circuits for the automobile industry, Transportation Research Procedia, 25, pp. 14161429, World Conference on Transport Research - WCTR 2016 Shanghai. 10-15 July 2016,

[14] FIA, List of FIA licensed circuits, https://www.fia.com/file/62695/download?token=rRB9F55I, Accessed 27 October 2018

[15] Statisticstimes.com, List of European countries by population, 2015, http://statisticstimes.com/population/european-countries-by-population.php, Accessed 15 May 2018

[16] P. Horton, https://rhombi8.wordpress.com/page/4/, Accessed 3 June 2018

[17] TECPRO barriers booklet, 2006.

[18] Vukobratović, N., Barišić, l., Dimter, S. 2017: Analyses of the influence of material characteristics on pavement design, Electronic Journal of the Faculty of Civil Engineering Osijek-e-GFOS, 14, pp. 8-19, https://doi.org/10.13167/2017.14.2

Please cite this article as:

Kmoniček, H.; Ruška, F.; Barišić, l.: Racing circuit and their geometric design characteristics, Electronic Journal of the Faculty of Civil Engineering Osijek-e-GFOS, 19, pp. 98-107, https://doi.org/10.13167/2019.19.10

Kmoniček, H, Ruška, F, Barišić, I 